\title{
Kewenangan Kepolisian Dalam Menangani Tindak Pidana Pertambangan (Ilegal Mining) Menurut Undang-Undang Nomor 4 Tahun 2009 (Studi Di Kepolisian Negara Indonesia)
}

\author{
Dany Andhika Karya Gita ${ }^{*}$, Amin Purnawan ${ }^{* *}$, Djauhari $^{* * *}$
}

\begin{abstract}
* Mahasiswa Program Magister (S2) Ilmu Hukum Fakultas Hukum UNISSULA Semarang, email danyandhika66@gmail.com

Dosen Fakultas Hukum UNISSULA Semarang

Dosen Fakultas Hukum UNISSULA Semarang
\end{abstract}

\begin{abstract}
This research is entitled The Authority of Police in Handling Mining Criminal Act According to Law Number 4 Year 2009 (Study in Indonesian National Police). The purpose of this research: 1) To know and analyze the authority of Police in handling illegal mining according to Law Number 4 Year 2009 regarding Mineral and Coal Mining. 2) To evaluate preventive and repressive efforts by the Police in illegal mining in Indonesia.

Research Result: 1) The authority of the Police is the authority as stipulated in Law Number 2 Year 2002 regarding the Police of the Republic of Indonesia. The duties and powers of the Police are regulated in detail in Chapter III. In the execution of duties (Articles 13 and 14), the Police are granted the authority described in Article 15 and Article 16 with further provisions in Article 17, Article 18, and Article 19. 2) a. Preventive efforts in conducting patrols, raids, security operations conducted routinely and provide socialization to the public about the importance of creating security and how to overcome illegal stone mining and approaching with local residents to do pekon not to do illegal mining activities. While repressive efforts are done by optimizing the efforts of prosecution and collect evidence to act legally illegal mining actors with the provision of sanctions firm and deterrent effect and through mediation of the parties litigation so that the perpetrators do not need to be processed through criminal sanctions.
\end{abstract}

Key Words: Police Authority, Crime, Mining

\section{ABSTRAK}

Penelitian ini berjudul Kewenangan Kepolisian Dalam Menangani Tindak Pidana Pertambangan (Ilegal Mining) Menurut Undang-Undang Nomor 4 Tahun 2009 (Studi di Kepolisian Negara Indonesia). Tujuan Penelitian ini : 1) Untuk mengetahui dan menganalisis kewenangan Polri dalam menangani ilegal miningmenurut Undang-Undang Nomor 4 Tahun 2009 tentang Pertambangan Mineral dan Batu Bara. 2) Untuk mengevaluasi upaya preventif dan upaya represif yang dilakukan oleh Polri dalam Tindak Pidana Pertambangan (ilegal mining) di Indonesia.

Hasil Penelitian : 1) Kewenangan Polri adalah wewenang yang tertuang dalam Undang-Undang Nomor 2 Tahun 2002 tentang Kepolisian Negara Republik Indonesia. Tugas dan wewenang Polri diatur secara terperinci di dalam Bab III. Dalam pelaksanaan tugas (Pasal 13 dan Pasal 14), Polri diberikan wewenang yang dijabarkan dalam Pasal 15 dan Pasal 16 dengan ketentuan lebih lanjut pada Pasal 17, Pasal 18, dan Pasal 19. 2) a. Upaya secara preventif yaitu melaksanakan patroli, razia, operasi keamanan yang dilakukan secara rutin dan memberikan sosialisasi kepada masyarakat tentang pentingnya menciptakan keamanan serta cara mengatasi penambangan batu ilegal serta melakukan 
pendekatan dengan warga sekitar melakukan rembuk pekon untuk tidak melakukan kegiatan penambangan batu secara liar. Sedangkan upaya represif yang dilakukan adalah dengan mengoptimalkan upaya penindakan serta menghimpun bukti-bukti guna menindak secara hukum pelaku penambangan batu secara liar dengan pemberian sanksi tegas dan berefek jera serta melalui mediasi terhadap para pihak yang berperkara sehingga pelaku tidak perlu di proses melalui sanksi pidana.

Kata Kunci : Kewenangan Kepolisian, Tindak Pidana, Pertambangan

\section{PENDAHULUAN}

Kekayaan SDA di Indonesia yang melimpah ini harus dapat dimanfaatkan dengan sebaikbaiknya guna meningkatkan taraf hidup dan perekonomian Bangsa. Oleh karena itu dibutuhkan Sumber Daya Manusia (SDM) yang berkualitas dan berkompeten sesuai dengan kekhususan bidangnya masing-masing. SDM yang berkualitas memiliki pengaruh besar terhadap pemanfaatan dan pencapaian hasil yang diharapkan sehingga dapat meningkatkan nilai pendapatan Negara. Hal tersebut di atas juga sesuai dengan Konstitusi kita sebagai landasan hukum tertinggi di Indonesia yaitu pada Pasal 33 (2), (3), (4) Undang-Uundang Dasar Negara Republik Indonesia Tahun 1945 yang berbunyi:

ayat (2), Cabang-cabang produksi yang penting bagi negara dan yang menguasai hajat hidup orang banyak dikuasai oleh negara; Ayat (3), Bumi dan air dan kekayaan alam yang terkandung di dalamnya dikuasai oleh negara dan dipergunakan untuk sebesar-besar kemakmuran rakyat; Ayat (4), Perekonomian nasional diselenggarakan berdasar atas demokrasi ekonomi dengan prinsip kebersamaan, efisiensi berkeadilan, berkelanjutan, berwawasan lingkungan, kemandirian, serta dengan menjaga keseimbangan kemajuan dan kesatuan ekonomi nasional. ${ }^{1}$

Pengertian pertambangan Menurut Pasal 1 angka 1 Undang-Undang Nomor 4 Tahun 2009 tentang Pertambangan Mineral dan Batu Bara adalah:

"pertambangan adalah sebagian atau seluruh tahapan kegiatan dalam rangka penelitian, pengelolaan dan pengusahaan mineral atau batubara yang meliputi penyelidikan umum, eksplorasi, studi kelayakan, konstruksi, penambangan, pengolahan dan pemurnian, pengangkutan dan penjualan, serta kegiatan pascatambang' ${ }^{2}$

Pengertian di atas mengisyaratkan bahwasannya seluruh kegiatan mulai dari proses penelitian sampai pada kegiatan pasca tambang merupakan serangkaian kegiatan yang harus dapat dipertanggungjawabkan secara hukum.

Sebagian atau keseluruhan tahapan dari setiap upaya penambangan SDA di atas harus memiliki dari lembaga negara yang ditunjuk dan memiliki kewenangan di dalamnya. Sehingga setiap upaya tersebut dapat dipertanggungjawabkan secara hukum disertai dengan dokumen sah yang dikeluarkan oleh pihak yang bersangkutan untuk menghindari hal-hal yang tidak diharapkan di kemudian hari.

Pertambangan tanpa izin atau yang biasa disebut ilegal mining ini tidak hanya merugikan negara secara finansial, tapi sering juga menjadi penyebab munculnya berbagai persoalan seperti kerusakan lingkungan, konflik sosial, kejahatan, ketimpangan nilai ekonomi atau bahkan mendorong terjadinya kemiskinan baru. Fenomena ilegal mining di beberapa wilayah bahkan sampai menggangu dan mengancam keamanan dan ketertiban masyarakat.

Di beberapa daerah, ilegal miningyang identik dengan pertambangan skala kecil tanpa alat dan

\footnotetext{
${ }^{1}$ Pasal 33 Undang-Uundang Dasar Negara Republik Indonesia Tahun 1945

${ }^{2}$ Pasal 1 angka 1 UU Nomor 4 Tahun 2009 tentang Pertambangan Mineral dan Batu Bara
} 
fasilitas keamanan yang memadai juga seringkali memakan korban jiwa dari para penambang. Medan yang sangat sulit, sistem keamanan personal yang tidak layak, alat dan obat-obat kesehatan yang tidak tersedia di sekitar lokasi, jauhnya fasilitas kesehatan dari lokasi pertambangan, serta tidak adanya pihak yang bertanggung jawab atas keselamatan nyawa para pekerja ini merupakan alasan-alasan konkrit mengapa masalah ilegal mining perlu mendapat perhatian yang cukup besar di Indonesia.

Gangguan kamtibmas akibat adanya ilegal miningmerupakan salah satu bentuk tanggung jawab Polri sebagaimana sesuai dengan bunyi Pasal 4 Undang-Undang Nomor 2 Tahun 2002 tentang Kepolisian Negara Republik Indonesia sebagai berikut:

"Kepolisian Negara Republik Indonesia bertujuan untuk mewujudkan keamanan dalam negeri yang meliputi terpeliharanya keamanan dan ketertiban masyarakat, tertib dan tegaknya hukum, terselenggaranya perlindungan, pengayoman, dan pelayanan kepada masyarakat, serta terbinanya ketenteraman masyarakat dengan menjunjung tinggi hak asasi manusia". ${ }^{3}$

Dan sejalan pula dengan tugas pokok Polri dalam Pasal 13 Undang-Undang Nomor 2 Tahun 2002 tentang Kepolisian Negara Republik Indonesia yang berisi sebagai berikut:

"Tugas pokok Kepolisian Negara Republik Indonesia adalah:

a. Memelihara keamanan dan ketertiban masyarakat;

b. Menegakkan hukum, dan

c. Memberikan perlindungan, pengayoman, dan pelayanan kepada masyarakat. ${ }^{4}$

llegal miningsebagai bagian dari kejahatan terhadap kekayaan negara merupakan bagian yang tidak dapat dipisahkan dari Undang-Undang Nomor 4 Tahun 2009. Namun, di dalam Undang-Undang Nomor 4 Tahun 2009 tidak ditemukan definisi dari pertambangan tanpa izin (ilegal mining) ini. llegal miningini merupakan terjemahan dari pertambangan yang tidak memiliki izin. Izin yang dimaksud adalah 3 jenis izin yang diakui dalam Undang-Undang Nomor 4 Tahun 2009. Ketiga izin tersebut adalah IUP (Izin Usaha Pertambangan), IPR (Izin Pertambangan Rakyat), dan IUPK (Izin Usaha Pertambangan Khusus). Hal ini secara tidak langsung disebutkan dalam Bab XIII Ketentuan Pidana, yang menyebutkan dengan tegas sanksi administratif maupun sanksi pidana terhadap pertambangan tanpa izin (ilegal mining).

Sebagai contoh terjadinya ilegal mining di beberapa daerah di Indonesia adalah penambangan pasir ilegal di daerah Lumajang-Jawa Timur yang berujung pada tewasnya aktivis anti tambang Salim kancil dan Tosan yang mengalami luka parah akibat penganiayaan yang diduga didalangi oleh Kepala Desa Selok Awar-awar, Kecamatan Pasirian, Kabupaten Lumajang. ${ }^{5}$ Penambangan Timah ilegal di Desa Mempayak, Kecamatan Damar, Kabupaten Belitung Timur di Kepulauan Bangka Belitung yang sudah sering memakan korban, salah satunya adalah Rosdi yang tertimbun di dalam lubang camui (sebutan untuk lubang besar lokasi tambang). ${ }^{6}$

Fenomena di atas tentu menunjukkan sebuah realitas tentang tidak berjalannya sistem Kamtibmas yang menjadi tugas dari Polri. Polisi yang digambarkan sebagai law enforcer dan sebagai crime fighter oleh masyarakat harus mampu mengambil inisiatif untuk mencegah para penjahat dan bukan baru bertindak apabila telah terjadi kejahatan (bersikap reactive). ${ }^{7}$

Tindakan pencegahan (preventif) yang dimaksud di atas tentu tidak dapat lepas dari sebuah

\footnotetext{
${ }^{3}$ Pasal 4 UU Nomor 2 Tahun 2002 tentang Kepolisian Negara Republik Indonesia

${ }^{4}$ Pasal 13 UU Nomor 2 Tahun 2002 tentang Kepolisian Negara Republik Indonesia

${ }^{5}$ http://www.bbc.com/indonesia/berita_indonesia/2015/10/151002_indonesia_lumajang_tambang

${ }^{6} \mathrm{http}: / /$ belitung.tribunnews.com/2017/10/05/kronologis-dua-pekerja-tambang-tewas-tertimbun-longsor-baru-semingguberoperasi

${ }^{7}$ Eko Budiharjo, Reformasi Kepolisian, Sahabat, Klaten, 1998, hlm 55
} 
inovasi atau terobosan yang dirancang sedemikian rupa dengan unsur: 1) Tujuan (objective), yaitu posisi kondisional maupun dimensional yang ditetapkan untuk diraih; 2) Strategi; Alternatif paling optimal dari berbagai alternatif yang dapat ditempuh untuk mencapai tujuan; 3) Program; langkahlangkah penjabaran strategi yang disusun dalam jadwal waktu; 4) Anggaran (budget), Yaitu sumbersumber yang dapat dialokasikan untuk melaksanakan program. ${ }^{8}$

Apabila keempat unsur di atas dapat terakomodir dalam sebuah strategi Polri yang baik serta pelaksanaan kewenangan yang professional oleh Polri maka sangat diharapkan dapat menekan angka terjadinya tindak pidana pada umumnya dan ilegal mining pada khususnya sebagai fokus penulisan karya ilmiah ini.

Dari uraian di atas, maka penulis sangat tertarik untuk menuangkan pemikirannya ke dalam sebuah karya ilmiah yang berjudul "Kewenangan Kepolisian Dalam Menangani Tindak Pidana Pertambangan (Ilegal Mining) Menurut Undang-Undang Nomor 4 Tahun 2009 (Studi di Kepolisian Negara Indonesia)".

Perumusan masalah dalam penelitian ini :

1. Apakah kewenangan Polri dalam Menangani ilegal miningmenurut Undang-Undang Nomor 4 Tahun 2009 tentang Pertambangan Mineral dan Batu Bara?

2. Apakah upaya preventif dan represif yang dilakukan oleh Polri dalam Tindak Pidana Pertambangan (ilegal mining) di Indonesia?

\section{Metode Penelitian}

Metode pendekatan yang digunakan dalam penelitian ini adalah : Penelitian hukum normatif meliputi penelitian terhadap asas- asas hukum, taraf sinkronisasi hukum ${ }^{9}$ dan Pendekatan penelitian yang digunakan adalah penelitian yuridis empiris, yaitu pendekatan penelitian yang dapat diamati di dalam kehidupan nyata.

Jenis penelitian yang dipergunakan dalam menyelesaikan tesis ini adalah metode penelitian deskriptif, yaitu penelitian yang dilakukan dengan cara meneliti bahan pustaka (data sekunder) atau penelitian hukum perpustakaan ${ }^{10}$.

Jenis data yang digunakan adalah data primer dan sekunder. Data primer adalah data yang diperoleh secara langsung. Data primer dalam penelitian ini mengacu terhadap data atau fakta-fakta dan kasus hukum yang diperoleh langsung melalui penelitian di lapangan termasuk keterangan dari responden yang berhubungan dengan objek penelitian dan praktik yang dapat dilihat serta berhubungan dengan obyek penelitian.

Data sekunder adalah data yang diperoleh tidak secara langsung. Data sekunder dalam penelitian ini dilakukan dengan cara studi kepustakaan. Data sekunder ini berguna sebagai landasan teori untuk mendasari penganalisaan pokok-pokok permasalahan yang ada dalam penelitian ini. Data sekunder dalam penelitian ini meliputi : Bahan hukum primer, Bahan hukum sekunder, dan tersier.

Bahan hukum primer, yang terdiri dari Undang-Undang Dasar Negara Republik Indonesia Tahun 1945; Undang-Undang Republik Indonesia Nomor 4 Tahun 2009 Tentang Pertambangan Mineral dan Batu Bara; Undang-Undang Nomor 2 Tahun 2002 tentang Kepolisian Negara Republik Indonesia; Undang-Undang Republik Indonesia Nomor 28 Tahun 1999 Tentang Penyelenggaraan

\footnotetext{
${ }^{8}$ Kunarto, Perilaku Organisasi Polri, Cipta Manunggal, Jakarta, 1997, hlm 266

${ }^{9}$ Soerjono Soekamto dan Sri Mamudji, 2001. Penelitian Hukum Normatif suatu Tinjauan Singkat Jakarta: Raja Grafindo Persada. hal. 13-14

10 Ediwarman, Monograf, Metodologi Penelitian Hukum, Medan: Program Pascasarjana Universitas Muhammadiyah Sumatera Utara, Medan, 2010, hal. 24
} 
Negara Yang Bersih dan Bebas Dari. Korupsi, Kolusi, dan Nepotisme; Peraturan Presiden; Peraturan Menteri ESDM; dan Peraturan Daerah.

Bahan hukum sekunder meliputi Buku-buku, jurnal, dan dokumen hasil penelitian di bidang hukum khususnya masalah Kewenangan Kepolisian Dalam Menangani Tindak Pidana Pertambangan. Menurut Undang-Undang Nomor 4 Tahun 2009 (Studi di Kepolisian Negara Indonesia, dan sarana ajar (hand out) tentang tata cara penulisan karya ilmiah. Bahan Hukum Tersier, yang terdiri dari :Kamus Bahasa Indonesia, Kamus Bahasa Inggris, Kamus Hukum, Ensiklopedia.

Metode Pengumpulan Data yang digunakan meliputi: a) Kepustakaan, Penelitian ini menggunakan Library Research (studi kepustakaan) yaitu pengumpulan data yang diperoleh dari sumber-sumber literature, karya ilmiah, peraturan perundang-undangan serta sumber-sumber tertulis lainnya yang berhubungan dengan masalah yang diteliti sebagai landasan teori. Dari penelitian ini data yang diperoleh disebut data sekunder; b) Observasi, Observasi yaitu pengumpulan data dan fenomena-fenomena di lapangan sebelum dilakukan penelitian, c. Wawancara, Dalam penelitian ini melakukan wawancara terhadap informan.

Metode analisa data yang digunakan adalah deskriptif kualitatif, yaitu penguraian dari analisa data yang bertitik tolak pada informasi-informasi yang didapat dari responden untuk mencapai kejelasan masalah yang akan dibahas.

\section{HASIL PENELITIAN DAN PEMBAHASAN}

\section{Kewenangan Polri dalam Menangani illegal mining menurut Undang-Undang Nomor 4 Tahun 2009 Tentang Pertamabangan Mineral dan Batu Bara.}

Istilah kewenangan sering disebut authority, gezag, atau yurisdiksi dan istilah wewenang disebut competence atau bevoegdheid. Kewenangan (authority/gezag) adalah kekuasaan yang diformalkan baik terhadap segolongan orang tertentu maupun terhadap sesuatu bidang pemerintah tertentu secara bulat. Kekuasaan tersebut dapat berasal dari kekuasaan legislative ataupun dari kekuasaan eksekutif, sedangkan wewenang hanya mengenai sesuatu bidang tertentu saja. Dengan demikian kewenangan berarti kumpulan wewenang. ${ }^{11}$

Secara yuridis, pengertian wewenang adalah kemampuan untuk melakukan sesuatu tindakan hukum publik atau kemampuan bertindak yang diberikan oleh Undang-Undang untuk melakukan hubungan-hubungan hukum. ${ }^{12}$

Kewenangan Polri adalah wewenang yang tertuang dalam Undang-Undang Nomor 2 Tahun 2002 tentang Kepolisian Negara Republik Indonesia. Tugas dan wewenang Polri diatur secara terperinci di dalam Bab III. Dalam pelaksanaan tugas (Pasal 13 dan Pasal 14), Polri diberikan wewenang yang dijabarkan dalam Pasal 15 dan Pasal 16 dengan ketentuan lebih lanjut pada Pasal 17, Pasal 18, dan Pasal 19.

Kejahatan pertambangan tanpa izin/illegal mining merupakan kejahatan dalam usaha pertambangan yang dilakukan oleh perseorangan, sekelompok orang, atau perusahaan/yayasan berbadan hukum yang dalam operasinya tidak memiliki izin dari instansi pemerintah sesuai peraturan yang berlaku, yang ancaman sanksi pidana bagi barangsiapa yang karena kesalahannya melanggar larangan tersebut. Ketentuan pidana terhadap kejahatan pertambangan tanpa izin/illegal mining diatur dalam Undang-Undang Nomor : 4 Tahun 2009 Tentang Pertambangan Mineral dan Batubara,

\footnotetext{
${ }^{11}$ Prajudi Atmosudirdjo, Hukum Administrasi Negara, Ghalia Indonesia, Jakarta, 1981, hlm 29

${ }^{12}$ Yurizal, Reformulasi Kewenangan Polri dan PPNS Dalam Penyidikan Tindak Pidana Lingkungan Hidup, Banyumedia Publishing, Malang, 2014, hlm 39
} 
yang diatur dalam Pasal 158, Pasal 160 Ayat (1) dan Ayat (2), Pasal161, Pasal 163 Ayat (1) dan Ayat (2), dan Pasal 164.

\section{Upaya preventif dan represif yang dilakukan oleh Polri dalam Tindak Pidana Pertambangan (ilegal mining) di Indonesia}

Upaya pencegahan kejahatan merupakan upaya awal dalam menanggulangi kejahatan. Upaya dalam menanggulangi kejahatan dapat diambil beberapa langkah meliputi langkah penindakan (represif) disamping langkah pencegahan (preventif).

Langkah-langkah preventif tersebut meliputi:

1. Peningkatan kesejahteraan rakyat untuk mengurangi pengangguran, yang dengan sendirinya akan mengurangi kejahatan.;

2. Memperbaiki sistem administrasi dan pengawasan untuk mencegah terjadinya penyimpanganpenyimpangan;

3. Peningkatan penyuluhan hukum untuk memeratakan kesadaran hukum rakyat;

4. Menambah personil Kepolisian dan personil penegak hukum lainnya untuk lebih meningkatkan tindakan represif maupun preventif;

5. Meningkatkan ketangguhan moral serta profesionalisme bagi para pelaksana penegak hukum. ${ }^{13}$

Fungsi penegakan hukum diharapkan dapat mencegah orang (melakukan tindak pidana). Dalam konteks kehadiran polisi berseragam ditengah-tengah masyarakat dimaksudkan sebagai upaya prevensi. Kehadiran dan keberadaan polisi dianggap mengandung preventive effect yang memiliki daya cegah (detterent effort) anggota masyarakat dalam melakukan tindak pidana. ${ }^{14}$

Tindakan represif adalah segala tindakan yang dilakukan oleh aparatur penegak hukum sesudah terjadinya tindakan pidana. ${ }^{15}$

Upaya represif oleh Polri dilakukan dengan melihat berbagai faktor yang mempengaruhi pelaku tindak pidana. Faktor tersebut di antaranya:

1. Lingkungan dan kebiasaan di sekitar tempat tinggal tumbuh dan kembangnya;

2. Keadaan sosial ekonomi pelaku tindak pidana;

3. Psikologi pelaku tindak pidana (traumatik atau depresi);

4. Latar belakang keluarganya;

5. Tingkat pendidikan yang dimilikinya.

Dengan memperhatikan beberapa faktor diatas dipadukan dengan kecakapan skill komunikasi dan interaksi dengan para pelaku tindak pidana diharapkan tidak akan terjadi pengulangan tindak pidana baik dalam bentuk yang sama maupun berbeda.

Kegiatan Penambangan bahan galian golongan $\mathrm{C}$ khususnya pasir dan batu yang dilakukan masyarakat sebagaimana yang dilakukan pada areal-areal pertanian, pegunungan, bukit dan lain sebagainya dipandang telah membahayakan keselamatan jiwa manusia dan mengancam tata lingkungan hidup. Guna mencegah timbulnya korban jiwa dan dalam rangka menjaga kelestarian kawasan sekitar penambangan serta dalam upaya memperbaiki kondisi lingkungan yang rusak akibat kegiatan eksploitasi dan eksplorasi bahan tambang, maka diumumkan kepada masyarakat:

1. Dihimbau kepada masyarakat untuk menghentikan kegiatan penambangan.

2. Apabila dilapangan masih ditemukan kegiatan penambangan oleh masyarakat/pengusaha

\footnotetext{
${ }^{13}$ Baharuddin Lopa \& Moch Yamin, Undang-Undang Pemberantasan Korupsi, Alumni, Bandung, 2001, hlm 16

${ }^{14}$ Yurizal, Reformulasi Kewenangan Polri dan PPNS Dalam Penyidikan Tindak Pidana Lingkungan Hidup, Banyumedia Publishing, Malang, 2014, hlm 67

${ }^{15}$ Barda Nawawi Arief, Bunga Rampai Kebijakan Hukum Pidana, Citra Aditya Bhakti, Bandung, 1996, hlm 152
} 
tambang pasir dan batu pada daerah non aliran sungai sampai dengan tanggal 17 Februari 2009 maka akan dilakukan upaya penutupan oleh aparat penegak hukum bersama unsur terkait sesuai dengan peraturan perundangan yang berlaku, yaitu :

a. UU No. 23 Tahun 1997 tentang Pengelolaan Lingkungan Hidup dan segala Peraturan Pelaksanaannya.

b. Peraturan Daerah Propinsi Jawa Tengah No. 21 Tahun 2003 tentang Rencana Tata Ruang Wilayah Propinsi Jawa Tengah (Lembaran Daerah Propinsi Jawa Tengah) Tahun 2003 Nomor 133.

3. Dihimbau kepada aparatur pemerintah Desa/Kelurahan untuk dapat berperan aktif dan berpartisipasi dalam upaya sosialisasi dan pembinaan kepada masyarakat.

Itulah Pengumuman yang dibuat oleh Pemkab yang dikeluarkan untuk menyikapi penambangan yang semakin hari dirasa semakin mengkhawatirkan, baik dari aspek kerusakan lingkungan yang ditimbulkan maupun bahaya keselamatan jiwa manusianya.

\section{PENUTUP}

\section{Kesimpulan}

1. Kewenangan Polri adalah wewenang yang tertuang dalam Undang-Undang Nomor 2 Tahun 2002 tentang Kepolisian Negara Republik Indonesia. Tugas dan wewenang Polri diatur secara terperinci di dalam Bab III. Dalam pelaksanaan tugas (Pasal 13 dan Pasal 14), Polri diberikan wewenang yang dijabarkan dalam Pasal 15 dan Pasal 16 dengan ketentuan lebih lanjut pada Pasal 17, Pasal 18, dan Pasal 19. Kejahatan pertambangan tanpa izin/illegal mining merupakan kejahatan dalam usaha pertambangan yang dilakukan oleh perseorangan, sekelompok orang, atau perusahaan/yayasan berbadan hukum yang dalam operasinya tidak memiliki izin dari instansi pemerintah sesuai peraturan yang berlaku, yang ancaman sanksi pidana bagi barangsiapa yang karena kesalahannya melanggar larangan tersebut. Ketentuan pidana terhadap kejahatan pertambangan tanpa izin/illegal mining diatur dalam Undang-Undang Nomor : 4 Tahun 2009 Tentang Pertambangan Mineral dan Batubara, yang diatur dalam Pasal 158, Pasal 160 Ayat (1) dan Ayat (2), Pasal161, Pasal 163 Ayat (1) dan Ayat (2), dan Pasal 164.

2. Upaya Kepolisian dalam menangggulangi penambangan batu ilegal melalui 2 upaya, yaitu

a. Upaya secara preventif yaitu melaksanakan patroli, razia, operasi keamanan yang dilakukan secara rutin dan memberikan sosialisasi kepada masyarakat tentang pentingnya menciptakan keamanan serta cara mengatasi penambangan batu ilegal serta melakukan pendekatan dengan warga sekitar melakukan rembuk pekon untuk tidak melakukan kegiatan penambangan batu secara liar.

b. Sedangkan upaya represif yang dilakukan adalah dengan mengoptimalkan upaya penindakan serta menghimpun bukti-bukti guna menindak secara hukum pelaku penambangan batu secara liar dengan pemberian sanksi tegas dan berefek jera serta melalui mediasi terhadap para pihak yang berperkara sehingga pelaku tidak perlu di proses melalui sanksi pidana.

\section{DAFTAR PUSTAKA}

\section{A. Buku}

Baharuddin Lopa \& Moch Yamin, Undang-Undang Pemberantasan Korupsi, Alumni, Bandung, 2001. Barda Nawawi Arief, Bunga Rampai Kebijakan Hukum Pidana, Citra Aditya Bhakti, Bandung, 1996. 
Ediwarman, Monograf, Metodologi Penelitian Hukum, Medan: Program Pascasarjana Universitas Muhammadiyah Sumatera Utara, Medan, 2010.

H.D. Van Wiljk/William Konijenbelt dalam Yurizal, Reformulasi Kewenangan Polri dan PPNS Dalam Penyidikan Tindak Pidana Lingkungan Hidup, Banyumedia Publishing, Malang, 2014.

Kunarto, Perilaku Organisasi Polri, Cipta Manunggal, Jakarta, 1997.

Prajudi Atmosudirdjo, Hukum Administrasi Negara, Ghalia Indonesia, Jakarta, 1981.

Soerjono Soekamto dan Sri Mamudji, 2001. Penelitian Hukum Normatif suatu Tinjauan Singkat Jakarta: Raja Grafindo Persada.

Yurizal, Reformulasi Kewenangan Polri dan PPNS Dalam Penyidikan Tindak Pidana Lingkungan Hidup, Banyumedia Publishing, Malang, 2014.

Yurizal, Reformulasi Kewenangan Polri dan PPNS Dalam Penyidikan Tindak Pidana Lingkungan Hidup, Banyumedia Publishing, Malang, 2014.

\section{B. Perundang-undangan}

Undang-Undang Dasar Negara Republik Indonesia Tahun 1945.

Undang-Undang Republik Indonesia Nomor 4 Tahun 2009 Tentang Pertambangan Mineral dan Batu Bara

Undang-Undang Nomor 2 Tahun 2002 tentang Kepolisian Negara Republik Indonesia;

Undang-Undang Republik Indonesia Nomor 28 Tahun 1999 Tentang Penyelenggaraan Negara Yang Bersih dan Bebas Dari Korupsi, Kolusi, dan Nepotisme.

Peraturan Presiden;

Peraturan Menteri ESDM; dan

Peraturan Daerah.

\section{Jurnal atau Artikel}

Philipus M. Hadjon, Tentang Wewenang Pemerintahan (bestuurbevoegdheid), Majalah Pro Justitia XVI (1)

Ridwan, 2009, “Kebijakan Penegakan Hukum Pidana dalam Pemberantasan Tindak Pidana Korupsi di Indonesia"Jurnal Jure Humano, Volume1 No.1.

D. Internet

http://www.bbc.com/indonesia/berita indonesia/2015/10/151002 indonesia lumajang tambang http://belitung.tribunnews.com/2017/10/05/kronologis-dua-pekerja-tambang-tewas-tertimbunlongsor-baru-seminggu-beroperasi 